ISSN 1392-3196 / e-ISSN 2335-8947

Zemdirbyste-Agriculture, vol. 103, No. 2 (2016), p. 143-150

DOI 10.13080/z-a.2016.103.019

\title{
Energy value of biomass produced on various land uses in a sandy loam Haplic Luvisol
}

\author{
Asta KAZLAUSKAITE-JADZEVICE, Saulius MARCINKONIS, Eugenija BAKSIENE \\ Vokė Branch, Lithuanian Research Centre for Agriculture and Forestry \\ Žalioji 2, Vilnius, Lithuania \\ E-mail: asta.kaz@gmail.com; saulius.marcinkonis@gmail.com
}

\begin{abstract}
The article discusses the changes in energy accumulation in the biomass during a 21 -year arable land renaturalisation process. The relevance of renaturalisation studies in South-Eastern Lithuania is determined by the low-productivity of the soil covers in this area and low energy production obtained from traditional agricultural crops grown on lowproductivity agricultural soils. The aim of this study is to evaluate various methods of sandy loam Haplic Luvisol renaturalisation by comparing the total energy accumulated on pine afforested land use, unmanaged and managed grasslands against the productivity of the traditional agricultural systems. The accumulation of the total energy under various land uses was governed by the plants and their cultivation period. Downward trend of productivity during the period of $1995-2015$ : forest plants $(195 \%) \rightarrow$ fertilized managed grassland $(162 \%) \rightarrow$ fertilized cropland $(100 \%) \rightarrow$ unfertilized managed grassland $(95 \%) \rightarrow$ unfertilized cropland $(61 \%) \rightarrow$ unmanaged grassland $(50 \%)$. When comparing the plant biomass production during the entire study period, it was established that mineral NPK fertilization significantly (by 1.63 times) increased the energy productivity of the cropland. It is expedient to preserve and expand the managed grasslands typical of the traditional Lithuanian landscape and crucial for the conservation of biodiversity. Furthermore, the productivity of unfertilized managed grassland is adequate to the productivity of the fertilized cropland, or exceeds it by $67 \%$ if NPK fertilizers are applied. Mineral NPK fertilization significantly (by 1.71 times) increased the accumulated total energy of the managed grassland. The accumulation of energy changes significantly in the fallowing fields. Natural vegetation plants of non-cultivated sandy loam are not productive; they produce only half the amount of the total energy compared with the cropland plants or fertilized managed grasslands.
\end{abstract}

Key words: aboveground biomass, cropland, fallow, grassland, pine forest.

\section{Introduction}

Sandy soils of South-Eastern Lithuania are of low productivity and diverse soil cover varies depending on the ability of soil to accumulate organic carbon and maintain adequate moisture regime. In low-productivity sandy soils the yield is limited by moisture and often, although fertilizers are used, its shortage results in poor crop yield. Farmers in low-productivity soil areas generally incur losses and, therefore, planting of forests and grasslands can offer the solutions preventing the soil from fallowing thus making its use more purposeful and effective (Callesen, Ostergaard, 2008).

In order to meet the goals of multi-landscaping, environmental biodiversity conservation, gas emission reduction, development of energy resources and different ways of renaturalisation could be selected; they are considered as positive factors from the environment conservation viewpoint. Non-agricultural activities and afforestation could increase the area of forests instead of throughout long time predominant agrarian landscape, and the renaturalisation by establishing grasslands could expand the areas of natural and managed grasslands that are typical of traditional Lithuanian landscape and crucial to the conservation of biodiversity. A specific land use must be evaluated in a complex, since it preconditions the cultivation of certain plants and the amount of the obtained biomass, which then can be used in various applications including food, feed, fibre or energy.

In Lithuania, the use of the accumulated agricultural biomass for production of biofuels gains increasing popularity, since it involves less pollution and is promoted and enhanced on the political level and leads to energy independence and diversification of energy sources (European Energy..., 2014). Biomass is an attractive renewable energy resource that could promote the development of heat energy, fuel production and new technologies (Cosentino et al., 2008). Although renewable energy sources are not as efficient as fossil sources, they have other advantages - no need for import and less pollution. In the course of soil renaturalisation processes, not only the minimal impact on the environment is very important, but lower costs of obtaining biomass of higher energy value are also essential (Renewable energy..., 2012). In Lithuania, research on the evaluation of plant biomass as energy resource is concentrated on 
grassland (Tilvikienè et al., 2012; Kadžiulienè et al., 2013; Skuodiené et al., 2013), less frequently on forest (Armolaitis et al., 2013) plant experiments; the use of crop rotation biomass for energy is not very popular (Šarauskis et al., 2014; Povilaitis et al., 2016).

Researchers of various fields - agronomists, foresters, geographers and biologists emphasize the need for studies of renaturalisation processes, which encompass the monitoring of all types of land uses. In this way it is possible to measure the impact of different ways of conversion upon soil fertility. Efficiency of the conversion of unproductive arable land into other land uses could be assessed in various aspects - energy productivity, carbon sequestration, soil fertility changes, social, environmental, etc. Their general assessment may provide a reasonable answer about the most appropriate land uses in sandy loam soils. Total biomass energy is a quantitative measure and one of the factors that, when expressed, allows the calculations of energy balance in different land uses and reflects the impact of the soil and local conditions as well as plant cultivation potential (Cosentino et al., 2008). Economic and environmental considerations renewed the interest in opportunities to improve plant cenoses, simultaneously maintaining a sustainable use of soil and sustainable functioning of agroecosystems (Durkaya et al., 2010).

The aim of this study is to evaluate various methods of sandy loam renaturalisation by comparing the total energy accumulated during the cultivation of pine afforested site, unmanaged and managed grasslands with the productivity of the traditional agricultural systems.

\section{Materials and methods}

Experimental site and set up. Experimental sites of the field trial were arranged in 1995 in the field

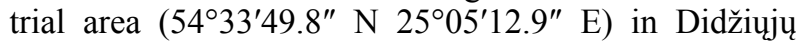
Lygainiu village, Vilnius district (Fig. 1). Experimental sites are located in South-Eastern Lithuania, in the zone with prevailing soil of a very low agronomic value; the basic soil fertility is evaluated by $<37$ points (The productivity..., 2011). Geomorphologically it is a fluvioglacial area; the terrain is a slightly undulating plain with a small inclination to the south.

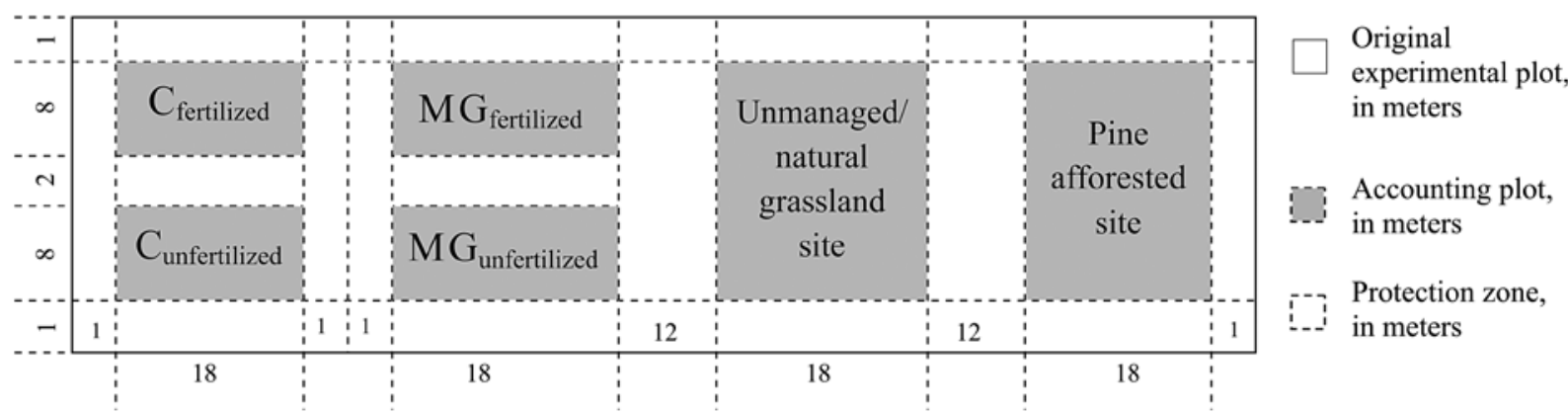

$\mathrm{C}$ - cropland site (control), subdivided into fertilized $\left(\mathrm{C}_{\text {fertilized }}\right)$ and unfertilized $\left(\mathrm{C}_{\text {unfertilized }}\right)$ subplots; $\mathrm{MG}-\operatorname{managed} /$ cultural grassland site, subdivided into fertilized $\left(\mathrm{MG}_{\text {fertilized }}\right)$ and unfertilized $\left(\mathrm{MG}_{\text {unfertilized }}\right)$ subplots

Figure 1. Design of the experiment

Experimental sites are arranged in continuously cultivated cropland on a sandy loam Haplic Luvisol. Experiment design comprised medium (unmanaged and managed grasslands) and long (afforestation) term treatments of land-use change. The arrangement of this experimental site and results of the first few years are presented in the publications of Petrovas (1999; 2000; 2001). The record area of each experimental site is $324 \mathrm{~m}^{2}(18 \times 18 \mathrm{~m})$.

During the period of 1995 to 2004, various agricultural crops were cultivated in the cropland site; their relative share during the study period was the following: perennial grasses $(20 \%)$, row plants $(30 \%)$, cereal crops $(30 \%)$ and cereal crops with perennial grasses undercrop (20\%); in 2005 the fallow was left in the cropland site; from 2006 up to 2015 oil plants $(10 \%)$, buckwheat family $(40 \%)$, perennial grasses $(10 \%)$, leguminous plants $(10 \%)$ and cereal crops $(30 \%)$ were cultivated. Cropland site was subdivided into two subplots; one subplot was unfertilized, while in the other subplot mineral NPK fertilizers were used according to the soil nutrient status (Table 1). Ammonium nitrate, superphosphate and potassium chloride were used as fertilizers. In cropland site, crop sowing and maintenance were carried out in accordance with the recommended cultivation technologies.
In managed grassland site, leguminous plants (Fabaceae) (40\%) and a mixture of 4 monocotyledonous (Poaceae) grasses (60\%) were cultivated. In 19952006 , in this site hybrid alfalfa (Medicago varia L.) and a mixture of 4 grasses: red fescue (Festuca rubra L.), bromegrass (Bromus inermis Leyss.), orchard grass (Dactylis glomerata L.) and common meadow-grass (Poa pratensis L.) were cultivated. After 12 years of research, as the grassland grew old, it was re-sown in 2007, and during 2008-2015 hybrid alfalfa (Medicago varia L.) and a mixture of four grasses: tall fescue (Festuca arundinacea Schreb.), bromegrass (Bromus inermis Leyss.), timothy (Phleum pratense L.) and meadow grass (Poa pratensis L.) were cultivated.

Managed grassland site was subdivided into two subplots; one subplot was unfertilized, while in the other subplot mineral NPK fertilizers were used. In spring after resumption of plant vegetation, $\mathrm{N}_{60} \mathrm{P}_{90} \mathrm{~K}_{120}$ mineral fertilizers were used in the fertilized subplot, the grass was cut twice.

No agro-technical activity was performed in the unmanaged grassland site and pine afforested site. During the investigation period, natural vegetation phytocenoses typical of sandy loam soils formed in the unmanaged grassland site; its composition varied depending on hydrothermal conditions of the growing season. Scots 
Table 1. Cropland plants and their fertilization in $\mathrm{C}_{\text {fertilized }}$ site

\begin{tabular}{|c|c|c|c|c|}
\hline \multirow{2}{*}{ Year } & \multirow{2}{*}{ Cropland plants } & $\mathrm{N}$ & $\mathrm{P}_{2} \mathrm{O}_{5}$ & $\mathrm{~K}_{2} \mathrm{O}$ \\
\hline & & \multicolumn{3}{|c|}{$\mathrm{kg} \mathrm{ha}^{-1}$} \\
\hline $1995,1999,2003$ & spring barley (Hordeum vulgare L. nutans) & 60 & 60 & 60 \\
\hline 1996,2000 & potato (Solanum tuberosum L.) (with $40 \mathrm{t} \mathrm{ha}^{-1}$ manure) & 90 & 60 & 120 \\
\hline 1997 & $\begin{array}{l}\text { spring barley (Hordeum vulgare L. nutans) and } \\
\text { red clover (Trifolium pratense L.) undercrop }\end{array}$ & 60 & 60 & 60 \\
\hline 1998,2002 & red clover (Trifolium pratense L.) & - & 90 & 120 \\
\hline 2001 & $\begin{array}{l}\text { triticale (Triticosecale Wittmack) and } \\
\text { red clover (Trifolium pratense L.) undercrop }\end{array}$ & 45 & 45 & 45 \\
\hline 2004 & potato (Solanum tuberosum L.) & 90 & 60 & 120 \\
\hline 2005 & fallow & - & - & - \\
\hline 2006 & spring rape (Brassica napus L.) & 100 & 50 & 70 \\
\hline $2007,2011,2012,2015$ & buckwheat (Fagopyrum esculentum Moench) & 30 & 30 & 30 \\
\hline 2008 & $\begin{array}{l}\text { spring wheat (Triticum aestivum L.) and } \\
\text { red clover (Trifolium pratense L.) undercrop }\end{array}$ & 60 & 30 & 30 \\
\hline 2009 & red clover (Trifolium pratense L.) & 0 & 30 & 60 \\
\hline 2010,2014 & winter rye (Secale cereale L.) & 60 & 30 & 30 \\
\hline 2013 & narrow-leaved lupine (Lupinus angustifolius L.) & - & 30 & 30 \\
\hline
\end{tabular}

pine (Pinus sylvestris L.) grew in the pine afforested site; the density of a 10 year-old site (in 2004) was 8547 trees $\mathrm{ha}^{-1}$; in 2009 the thinning of the site was performed. The density of 21 year-old (in 2015) trees was 3509 trees ha $^{-1}$.

Plant yield evaluation and energy assessment of biomass productivity. Crop yield records in the cropland site were taken at full maturity stage, at the managed grassland site the first cutting was performed at alfalfa flowering stage, the second cutting - during the second ten-day period of August. Vegetation mass of the unmanaged grassland was determined once during the growing season, at the second ten-day period of June, on the area of $0.25 \mathrm{~m}^{2}$. The number of replications was four. The dry matter content in plants was determined after the samples had been dried to constant moisture at $105^{\circ} \mathrm{C}$. Biomass of natural humidity and dry biomass of the main and secondary plant production were assessed, excluding root biomass. Potato tubers were evaluated as the main production (Bolinder et al., 2007).

Volume of the pine afforested site was determined considering the tree diameter (at $1.30 \mathrm{~m}$ height) as well as the tree height and density. Data processing and pine plantation volume calculations were performed using the program developed at the Institute of Forestry, Lithuanian Research Centre for Agriculture and Forestry, which is intended for calculation of dendrometric (forest valuation) indicators of tree stands. Tree branches and needles were included into the tree volume records (Global Forest..., 2015).

Biomass of straw, grain, perennial grasses and pine trees is converted into a total energy (TE). Total energy of cropland site, managed grassland site and unmanaged grassland site is calculated using the NeringZincenko equation (The productivity..., 2011):

$$
\mathrm{TE}=\left(0.0238 \times \mathrm{CP}+0.03972 \times \mathrm{CF}_{1}+0.0188 \times\right.
$$
$\left.\mathrm{CF}_{2}+0.0175 \times \mathrm{NFE}\right)$

where TE is total energy, $\mathrm{MJ} \mathrm{kg}^{-1} \mathrm{dm}, \mathrm{CP}-$ crude protein, $\mathrm{CF}_{1}$ - crude fat, $\mathrm{CF}_{2}$ - crude fibre, NFE -nitrogen-free extractive substances, $\mathrm{g} \mathrm{kg}^{-1} \mathrm{dm}$.

For calculations, $\mathrm{CP}, \mathrm{CF}_{1}, \mathrm{CF}_{2}$ and NFE values of particular plants according to the manual "Chemical composition and nutritional value of fodder" were used (Tamulis, 1986). Yield sum of dry matter yield of the main and secondary production in the cropland site was converted into biomass energy productivity. Tree volume in the pine afforested site was converted into total energy. Calculations were made according to the data of one of Sweden's largest forest companies "ÅF International", stating that one kilogram of dry wood corresponds to 19.2 MJ (Lindgren, Pedišius, 2003), and density of Scots pine wood is $420 \mathrm{~kg} \mathrm{~m}^{-3}$ (Lithuania's National..., 2014).

The experimental data were analysed by a one factor analysis of variance recommended in agronomy science. Significance of the difference between the means was determined according to the least significant difference (LSD) at 0.05 probability level. The data were processed using software ANOVA and Microsoft Office.

Meteorological conditions. In the course of the experimental period (1995-2015), the weather conditions of the plant growing season (April-September) were very different. The average air temperature during the growing season in Traku Vokè was $14.2^{\circ} \mathrm{C}$ (varied from $13.2^{\circ} \mathrm{C}$ to $15.5^{\circ} \mathrm{C}$ ) and was by $1.3^{\circ} \mathrm{C}$ higher than the standard climate norm (SCN) of April-September. The average rainfall was $373 \mathrm{~mm}$ (varied from 235 to 697 $\mathrm{mm}$ ) and was only by 7\% higher than the SCN (AprilSeptember).

During the study period, $19 \%$ of the years were very rainy, and $29 \%$ of the years were very droughty, compared with SCN (April-September). A similar situation was with temperatures $-19 \%$ of the years were very hot and average temperature during the growing season reached $15-15.5^{\circ} \mathrm{C}$. Much higher temperatures than the SCN (April-September) were recorded in 1999, 2002,2010 and $2011\left(>2.1 \ldots 2.6^{\circ} \mathrm{C}\right)$. In 2010 and 2011 , the rainfall was abundant and the average temperatures were by $2.2-2.4^{\circ} \mathrm{C}$ higher than the SCN (April-September). Lower and more close to the SCN (April-September) temperatures were in 1996, 1997, 1998, 2000, 2003 and $2004\left(>0.3 \ldots 0.9^{\circ} \mathrm{C}\right)$.

\section{Results and discussion}

Within the 21 years of the study, the data on the accumulation of total energy in biomass (cropland, managed and unmanaged grasslands) showed that 
productivity variation coefficients of different land uses were similar, still during separate years, due to changeable weather conditions, very high (from $42 \%$ to $63 \%$ ) variation of the accumulated total energy was recorded (Table 2). In the soil fertilized with mineral NPK the variations of total energy were smaller, indicating that the balanced fertilization increase crop resistance to adverse weather conditions, thus making the variations of total energy by $10-12 \%$ smaller. The managed grasses are more resistant to changes of hydrothermal conditions compared with the cropland plants; therefore smaller variation of the energy accumulated in the biomass was recorded $(42-54 \%)$.

Table 2. Accumulated total energy in different phytocenoses in 1995-2015, GJ ha-1

\begin{tabular}{cccccc}
\hline $\begin{array}{c}\text { Experimental } \\
\text { site }\end{array}$ & \multicolumn{3}{c}{ Total energy } & $\begin{array}{c}\text { The coefficient of } \\
\text { variation } \%\end{array}$ & $\begin{array}{c}\text { Sum of total } \\
\text { energy }\end{array}$ \\
\cline { 2 - 4 } $\mathrm{C}_{\text {fertilized }}$ & 6.35 & 117.65 & 51.88 & 53 & 1038 \\
\hline $\mathrm{C}_{\text {unfertilized }}$ & 3.75 & 104.19 & 31.86 & 63 & 637 \\
\hline $\mathrm{MG}_{\text {fertilized }}$ & 40.23 & 169.49 & 93.65 & 42 & 1686 \\
\hline $\mathrm{MG}_{\text {unfertilized }}$ & 19.72 & 126.04 & 54.71 & 54 & 585 \\
\hline $\begin{array}{c}\text { Unmanaged/natural } \\
\text { grassland site }\end{array}$ & 5.72 & 46.51 & 24.77 & 58 & 520 \\
\hline Pine afforested site & - & - & LSD $_{05}=16.595$ & - & 2024 \\
\hline
\end{tabular}

The summary of the annual data on total energy accumulation in cropland site biomass during 1995-2015 reveals that traditional agricultural system using average rates of mineral fertilizers in sandy loam soil yields the biomass accumulating an average of $51.88 \mathrm{GJ} \mathrm{ha}^{-1}$ of energy per year. Fertilizer use was very efficient and, compared with unfertilized cropland, the energy accumulation in plant biomass increased significantly by 1.63 times or $20.02 \mathrm{GJ}^{-1}$ per year $(P<0.05)$. According to the surveys of foreign researchers, the balanced NPK fertilization increased crop yield and consequently the energy accumulation, especially in infertile soils (Wang et al., 2015).

Annual analysis of plant productivity in traditional agricultural system revealed obvious differences in the productivity of various plants (Figs. 2-3). Fertilized potatoes accumulated the highest amount of total energy. Due to different meteorological conditions during the growing season, the amount of accumulated total energy in separate years varied 1.3-1.4 times, while in the case of similar conditions (1996, 2000 and 2004) the amounts of total energy did not essentially differ.

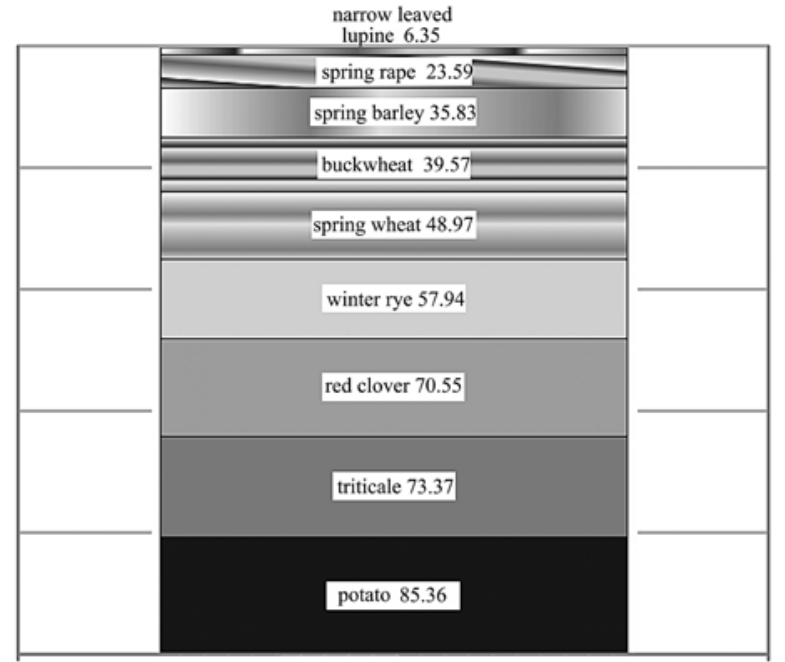

Figure 2. Productivity average $\left(\mathrm{GJ} \mathrm{ha}^{-1}\right)$ of different plants of fertilized cropland site, 1995-2015
In sandy loam soil, triticale and red clover accumulated slightly lower amount of total energy (triticale $16 \%$ and red clover $21 \%$ ) compared with potatoes. Unlike potatoes, perennial grasses were characterized by high productivity variation in separate years: during the dry year of 2002 biomass productivity of fertilized red clover was 2.8-4.8 times lower in comparison with the productivity obtained in 2009 and 1998. It should be noted that in 1998 fertilized cropland yielded the highest amount of total energy, and the same year the amount of total energy in fertilized grassland was also the highest, reaching 169.49 $\mathrm{GJ} \mathrm{ha}^{-1}$. Favourable weather conditions in 1998 with an average air temperature of the growing season close to the SCN and precipitation by $20 \%$ higher than the SCN led to higher amount of accumulated energy.

Studies of other researchers confirm that potatoes and perennial grasses accumulate the highest amounts of energy, barley and wheat - slightly less (Arbačiauskas et al., 2015). Above-ground biomass of triticale cultivated in traditional agricultural system (2001) was also high (73.37 $\mathrm{GJ} \mathrm{ha}^{-1}$ ), and during the study period triticale was the only crop that surpassed the amount of total energy accumulated by red clover (70.55 GJ ha-1). Meanwhile, above-ground biomass accumulation of winter rye, spring wheat (2008) and buckwheat was lower and amounted to 57.94, 48.97 and $39.57 \mathrm{GJ}^{-1} \mathrm{a}^{-1}$, respectively; even lower accumulation was observed in spring barley - an average of $35.83 \mathrm{GJ} \mathrm{ha}^{-1}$. Productivity of fertilized buckwheat varied 1.3-1.6 times during separate years $(2007,2011$, 2012 and 2015), while that of spring barley (1995, 1997, 1999 and 2003) - only 1.1-1.2 times.

Of all the cropland plants cultivated throughout the whole study period, spring rape was characterized by a particularly low amount of accumulated energy; these plants are more demanding in terms of soil fertility. The fertilized plants (in 2006) accumulated $23.59 \mathrm{GJ} \mathrm{ha}^{-1}$ per year. Compared with productive plants of the fertilized cropland subplot, the productivity of spring rape was on average 3 times lower. Therefore, if rape is cultivated in infertile soils, fertilization and plant protection measures should be very carefully selected in order to ensure competitive yields of these crops compared with 
conventional plants. The lowest amount of total energy in fertilized cropland subplot was recorded for narrowleaved lupine; it was as low as $6.35 \mathrm{GJ} \mathrm{ha}^{-1}$ (in 2013). Such low productivity was mainly due to anthracnose, which irreversibly damaged seeds, stems, stalks, inflorescences and pods. The studies performed in Lithuania show that widely spread anthracnose could reduce the grain yield of sensitive lupine varieties by as much as 1.5 to 3.3 times (Semaškienè, 2009). As a result, cultivation of plant species that are less sensitive to soil fertility could not prevent from the yield losses due to disease or pest damage.

In the unfertilized subplot, the differences in the productivity (up to 28 times) of various plants are also obvious; narrow-leaved lupine yielded the lowest biomass productivity - only $3.75 \mathrm{GJ}^{-1}$ (in 2013), and the highest productivity was recorded for red clover - 104.19 GJ ha-1 (in 1998). Clover and triticale are capable of the best use of potential soil fertility; they accumulate the highest amounts of total energy in unfertilized soil, meanwhile the productivity of potatoes reduces. Productivity of other plants in unfertilized cropland subplot in decreasing order was the following: winter rye, buckwheat, wheat, barley and the least productive were spring rape and narrowleaved lupine. Low energy accumulation by spring rape has been already noted (Vaišvila et al., 2015), but it could be increased with the help of mineral NPK fertilizers.

Compared with cropland site, the grassland phytocenosis was characterized by higher productivity as well as slightly higher difference of the average accumulated total energy between fertilized and unfertilized subplots (Fig. 3). During the study period, the fertilized subplot yielded $93.65 \mathrm{GJ}^{\mathrm{h}} \mathrm{h}^{-1}$ per year, while the unfertilized
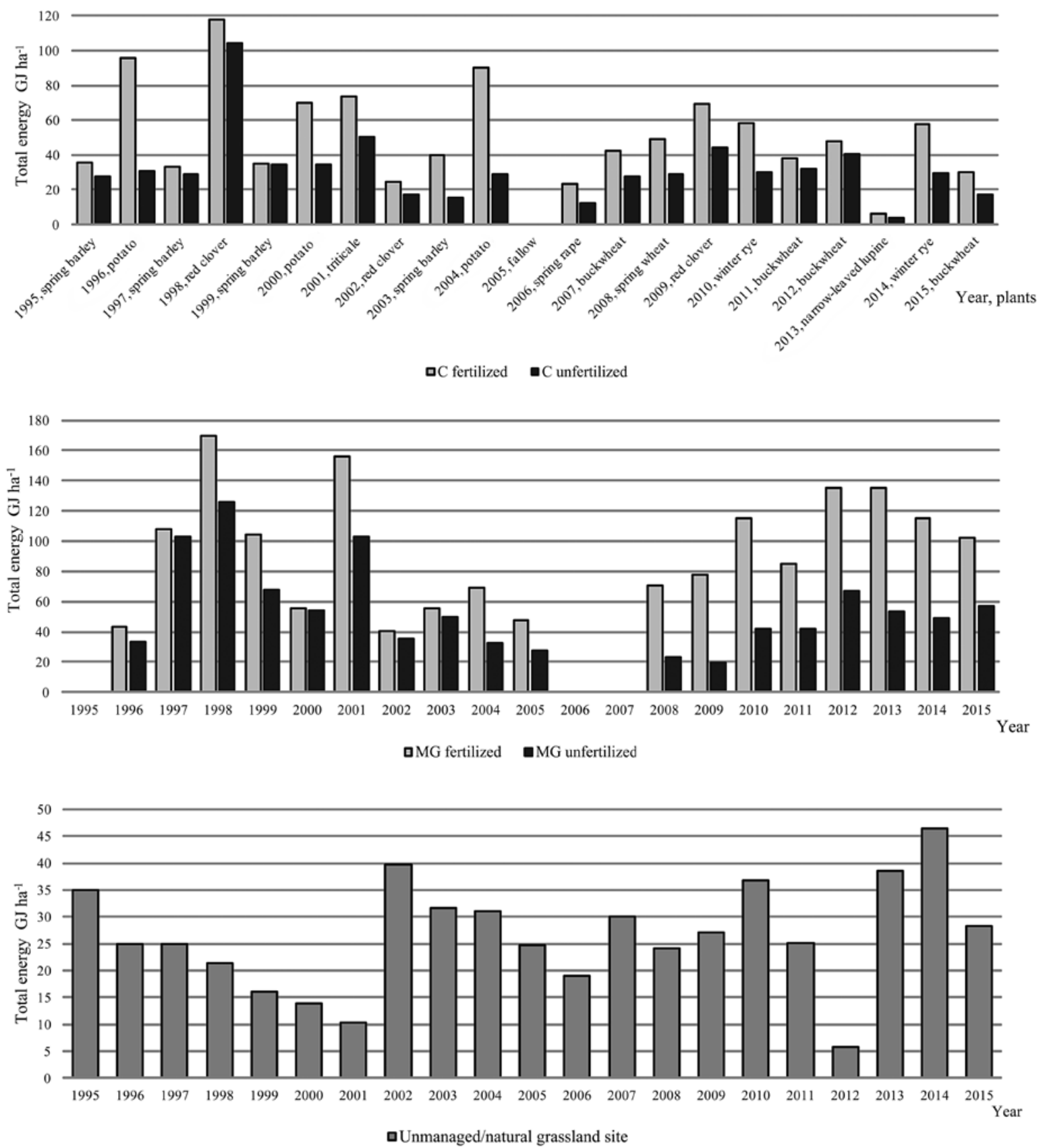

MG - managed/cultural grassland site

Figure 3. Total energy accumulated every year in different phytocenoses during 1995-2015 
- $54.71 \mathrm{GJ} \mathrm{ha}^{-1}$. Fertilization of managed grassland phytocenoses with mineral NPK fertilizers increased the annual energy accumulation by $38.94 \mathrm{GJ} \mathrm{ha}^{-1}$; therefore the fertilized managed grassland was significantly by 1.71 times more productive $(P<0.05)$. It was revealed that the yield of managed grassland, consisting of Poaceae grass sward, is best increased by nitrogen fertilizers and especially their interaction with the phosphorus and potassium fertilizers (Vaišvila et al., 2015).

Analysis of separate years shows the lowest productivity of fertilized grassland recorded in 2002 - $40.23 \mathrm{GJ} \mathrm{ha}^{-1}$, i.e. approximately 4.2 times lower than the maximum productivity in 1998. The survey of hydrometeorological conditions of the year 2002 showed that the reason for poor biomass yield was very dry $(36 \%$ less rainfall than the $\mathrm{SCN})$ and hot $\left(>2.6^{\circ} \mathrm{C}\right.$ higher temperature than the $\mathrm{SCN}$ ) growing season.

The highest yield of unfertilized grassland was also recorded in 1998 and amounted to $126.04 \mathrm{GJ} \mathrm{ha}^{-1}$, while the lowest yield was in 2009 and amounted to $19.72 \mathrm{GJ}^{-1}$, being by 6.4 times lower than the highest productivity.

When the fertilized cropland site is transformed into unmanaged grassland, the energy accumulation significantly changes $(P<0.05)$. During the entire study period, the average annual total energy accumulated in the unmanaged grassland was the lowest $\left(24.77 \mathrm{GJ} \mathrm{ha}^{-1}\right)$. Unmanaged grassland phytocenosis was by 2.2 times less productive in comparison even with the unfertilized managed grassland $(P<0.05)$; however, compared with unfertilized cropland cenosis, the productivity of unmanaged grassland only slightly differed and the difference was insignificant $(P>0.05)$. Undoubtedly, the cultivation of cropland plants without fertilization is irrational.

A detailed analysis of total energy accumulation of cropland in sandy loam soils reveals economically uncompetitive conditions of traditional agricultural systems that are dependent on low productivity, weather conditions and potential of cultivated crops. Unused and low-productivity land produces low amount of total energy. Meanwhile, research results on managed grasses growing in sandy loam soil indicate a good potential of these plants for total energy accumulation.

In a 21-year-old pine afforested site the accumulated total energy amounted to $2024 \mathrm{GJ} \mathrm{ha}^{-1}$, and even low-productivity sandy loam Haplic Luvisol allowed to obtain high amount of the accumulated total energy (195\% compared with the fertilized cropland).

While evaluating the soil renaturalisation processes, the analysis of the changes in the sum of total energy during various periods (1995-2004 and 2005-2015) was performed; it combined the productivity parameters of cropland, managed grassland and unmanaged grassland sites as well as the productivity of pine afforested site. It was assessed that during the first decade (1995-2004) the highest productivity was recorded for the pine afforested site - $1358 \mathrm{GJ} \mathrm{ha}^{-1}$. By $34 \%$ lower amount of accumulated energy of the pine afforested site during the second decade of renaturalisation (in 2005-2015) was due to wood thinning in 2009 and the slowdown of the forest increment after 2004 (Fig. 4).

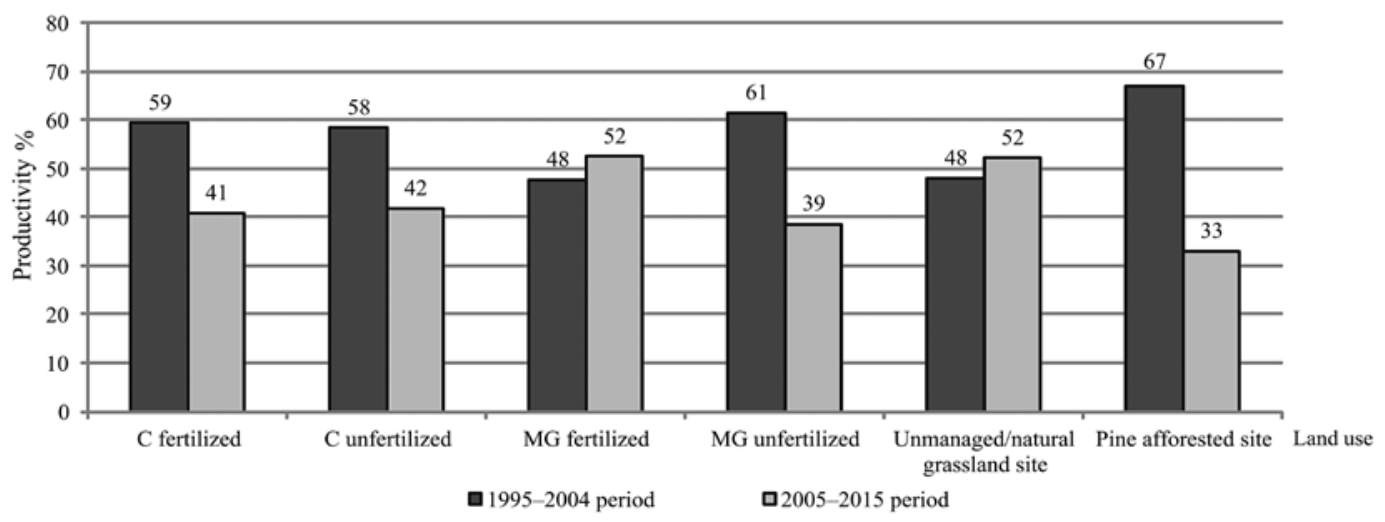

MG - managed/cultural grassland site

Figure 4. Relative productivity of phytocenoses in different land uses during 1995-2004 and 2005-2015 periods

Studies of other researchers confirm our experimental results on the effectiveness of afforestation of sandy soils of South-Eastern Lithuania. Balevičiūtè and Veteikis (2012) indicate that the processes of vegetation cover changes, forest formation are most rapid in sandy and sandy loam soils, slightly slower - in loams, and the slowest - in peat soils. After a certain period of time, although the forest is still very young, its growth is no longer as intense as during the first 10 years (Niskanen et al., 2008). Karpavičius (2004) showed that pine, as a species with a deep root system, is less sensitive to changing climatic conditions than other species, not to mention sensitive crop plants. However, in low-yield areas the processes of land conversion into forests and/ or natural forest overgrowth could not be downright promoted, because, under favourable weather conditions, other land uses could also accumulate similar amounts of total energy in their biomass.
Ahigh amount of total energy is also accumulated in fertilized grassland phytocenoses $(162 \%$ compared with the fertilized cropland site) where the total energy produced in the course of the study period amounted to $1686 \mathrm{GJ} \mathrm{ha}^{-1}$. The unfertilized grassland accumulated $985 \mathrm{GJ} \mathrm{ha}^{-1}$ of energy, and according to the productivity ( $95 \%$ compared with the fertilized cropland) equalled the fertilized cropland. However, when comparing the data of separate land uses, it should be noted that fallow was left in cropland site for a year and no yield was obtained then, and during the managed grassland renovation no yield was obtained for three years.

Studies have shown that in low-productivity soils of Eastern Lithuania (Vaičiulytè, Bakšienè, 2011) as well as soils of other groups and climatic conditions (Nemeikšienè et al., 2010; Alonso et al., 2012) perennial grasses produce really good yields and are more productive than other plants. These results show that it is appropriate 
to preserve and expand the managed grasslands that are characteristic of the traditional Lithuanian landscape and crucial for the conservation of biodiversity.

Transformation of cropland into unmanaged grassland fundamentally changes the energy accumulation in phytocenosis. Total energy accumulated during the first 10 years in the unmanaged grassland was $249 \mathrm{GJ} \mathrm{ha}^{-1}$, and for the entire study period amounted to $520 \mathrm{GJ} \mathrm{ha}^{-1}$. The low energy accumulation in unmanaged grassland biomass is due to lower productivity potential of naturally growing plants compared to crops. The unmanaged grassland phytocenosis accumulated the least energy $(50 \%)$, compared to fertilized cropland, so it is obvious that unmanaged grasslands are useless even in low-yield soils.

Despite the fact that grasslands originating as a result of fallowing are non-productive, part of them should be retained because of their importance to many farmland animals and insects, and with increasing production of biofuels and implementation of climate change mitigation policies, the other part of the unused land could become important for increasing bioenergy production.

Theperformedcomparison of energyproductivity resulting from the conversion of infertile arable lands is only one of the evaluation criteria for the selection of the most appropriate land use in light textured soils. The assessment of energy potential should be considered in parallel with the environmental, agronomic and biological aspects. The planning guidelines and the related decisionmaking on land use should be comprehensively analysed, taking into account local conditions.

\section{Conclusions}

1. Accumulation of total energy in phytocenoses of various land uses depends on the plant species and the duration of their cultivation. During the first decade of land use transformation, higher productivity was recorded in pine afforested site (1358 GJ ha-1) and fertilized managed grassland site ( $\left.803 \mathrm{GJ} \mathrm{ha}^{-1}\right)$. In the second decade, pine biomass increment reduced by half and became lower than that of managed grassland. Downward trend of productivity in the period of 1995-2015: forest plants $(195 \%) \rightarrow$ fertilized managed grassland $(162 \%) \rightarrow$ fertilized cropland $(100 \%) \rightarrow$ unfertilized managed grassland $(95 \%) \rightarrow$ unfertilized cropland $(61 \%) \rightarrow$ unmanaged grassland $(50 \%)$.

2. In sandy loam Haplic Luvisol, the accumulated total energy of cropland site is significantly influenced by the weather conditions, and this led to a very high (53$63 \%$ ) variation of total energy during separate years of study. Managed grasslands are more resistant to adverse weather conditions, and total energy accumulation in plant yield was characterized by lower variation $(42-54 \%)$.

3 . The use of recommended fertilizer rate for cropland plants enabled the accumulation of more than $70 \mathrm{GJ} \mathrm{ha}^{-1}$ in the biomass of potato, triticale and red clover. The cultivation of spring rape and narrow-leaved lupine is rather risky, because in the case of unfavourable growing conditions or high disease incidence their energy yield amounts to only from $6.35 \mathrm{GJ} \mathrm{ha}^{-1}$ (narrow-leaved lupine) to $23.59 \mathrm{GJ}^{\mathrm{ha}}{ }^{-1}$ (spring rape).

4. The use of mineral NPK fertilizers increased the total energy accumulation of cropland plants and managed grasslands on average by 1.63-1.71 times. Fertilization increased crop resistance to adverse weather conditions, resulting in $10-12 \%$ decrease of the total energy variation.
5. On low-productivity sandy loam Haplic Luvisols, bioenergy production is more rational than traditional agricultural systems (cropland) due to 1.62-1.95 times higher amount of accumulated energy. Meanwhile, areas of even lower productivity can be assigned for fallows to perform ecological biodiversity enhancement and conservation functions.

\section{Acknowledgements}

The paper presents research findings, which have been obtained through the long-term research programme "Biopotential and quality of plants for multifunctional use" implemented by Lithuanian Research Centre for Agriculture and Forestry.

Received 18012016

Accepted 05042016

\section{References}

Alonso I., Weston K., Gregg R., Morecroft M. 2012. Carbon storage by habitat: review of the evidence of the impacts of management decisions and condition of carbon stores and sources. Natural England Research Report NERR043, 44 p.

Arbačiauskas J., Vaišvila Z., Rainys K., Rudokas V., Mažvila J., Adomaitis T., Šumskis D. 2015. Relation of agricultural plant nutrition and yield with soil agrochemical properties. Innovative soil science and plant science solutions: monograph, p. 221-229 (in Lithuanian)

Armolaitis K., Varnagirytè-Kabašinskienė I., Stupak I., Kukkola M., Mikšys V., Wojcik J. 2013. Carbon and nutrients of Scots pine stands on sandy soils in Lithuania in relation to bioenergy sustainability. Biomass and Bioenergy, 54: $250-259$ http://dx.doi.org/10.1016/j.biombioe.2013.03.034

Balevičiūtė A., Veteikis D. 2012. Renaturalisation changes in Lithuanian landscape in 1995-2010. Geografija, 48 (2): 133-144 (in Lithuanian)

Bolinder M. A., Janzen H. H., Gregorich E. G., Angers D. A., VandenBygaart A. J. 2007. An approach for estimating net primary productivity and annual carbon inputs to soil for common agricultural crops in Canada. Agriculture, Ecosvstems and Environment. 118 (1-4): 29-42 http://dx.doi.org/10.1016/j.agee.2006.05.013

Callesen I., Ostergaard H. 2008. Energy efficiency of biomass production in managed versus natural temperate forest and grassland ecosystems. Cultivating the Future Based on Science: $2^{\text {nd }}$ conference of the International Society of Organic Agriculture Research ISOFAR. Modena, Italy, p. 578-581

Cosentino S. L., Copani V., Patanè C., Mantineo M. D’Agosta G. M. 2008. Agronomic, energetic and environmental aspects of biomass energy crops suitable for Italian environments. Italian Journal of Agronomy=Rivista di Agronomia, 2: 81-95

Durkaya A., Durkaya B., Atmaca S. 2010. Predicting the aboveground biomass of Scots pine (Pinus sylvestris L.) stands in Turkey. Energy Sources, Part A: Recovery, Utilization, and Environmental Effects. 32 (5): 485-493 http://dx.doi.org/10.1080/15567030802612473

European Energy Security Strategy. 2014. Communication from the Commission to the European Parliament and the Council. Brussels, Belgium, 24 p.

Global Forest Resources Assessment 2015. Country Report. FAO, Lithuania, 89 p.

Kadžiulienè Ž., Šarūnaitė L., Kadžiulis L. 2013. Seasonal dynamics of legume-grass herbage production and quality in a long-term pasture. Grassland Science in Europe, 18: 222-224

Karpavičius J. 2004. Radial growth peculiarities of different tree species and their dependence on various factors. Ekologija, 4: 23-31 (in Lithuanian)

Lindgren U., Pedišius N. 2003. EU biofuels program experience. Andersson L., Budrys R. (eds.). Forest fuel integration into forestry management: results of economic research on forestry management, technologies and forest fuel production in Lithuania, p. 18-21 (in Lithuanian) 
Lithuania's National Inventory Report 2014. Greenhouse gas emissions 1990-2012. Vilnius, 519 p.

Nemeikšienė D., Arlauskienė A., Maikštènienè S., Šlepetienè A. 2010. Carbon and nitrogen accumulation in agroecosystems of different perennial grasses. Vagos, 87 (40): 41-50 (in Lithuanian)

Niskanen A.-M., Stenvall N., Pakkanen A., Pulkkinen P. 2008. Comparison of growth and stem from characters of Pinus sylvestris clones and seedlings of the same origin in a 10 year field trial. Scandinavian Journal of Forest Research, 23 (6): 484-490 http://dx.doi.org/10.1080/02827580802512416

Petrovas M. 1999. Geobotanical studies of initial renaturalisation of agrophytocenoses in light soil monitoring program in Southeast Lithuania. Žemès ūkio mokslai, 3: 3-11 (in Lithuanian)

Petrovas M. 2000. On conservation need and prospects of lowproductivity soils of Southeast Lithuania. $3^{\text {rd }}$ conference of young scientists Lithuania without Science - Lithuania without Future. Vilnius, p. 206-213 (in Lithuanian)

Petrovas M. 2001. Issues of rational use of low productivity soils of Lithuania. Soils and their fertility on the turn of the centuries. Book 3. Relevant problems of soil fertility under modern conditions. Minsk, Belarus, p. 117-120 (in Russian)

Povilaitis V., Šlepetienè A., Šlepetys J., Lazauskas S., Tilvikienė V., Amalevičiūtė K., Feizienè D., Feiza V., Liaudanskienè I., Cesevičienè J., Kadžiulienė Ž., Kukujevas A. 2016. The productivity and energy potential of alfalfa, fodder galega and maize plants under the conditions of the nemoral zone. Acta Agriculturae Scandinavica, Section B: Soil and Plant Science. 66 (3): 259-266 http://dx.doi.org/10.1080/09064710.2015.1093651

Renewable energy technologies: cost analysis series. 2012 International Renewable Energy Agency, 1 (5): 50 p.
Semaškienė R. 2009. The fungal disease prevention in narrowleaved fodder and narrow-leaved green manure lupine crops. Žemès, maisto ūkio ir žuvininkystès $2008 \mathrm{~m}$. finansuojamų taikomujų tyrimų santraukos. Lietuvos Respublikos žemės ūkio ministerija, p. 17-19 (in Lithuanian)

Skuodienè R., Repšienè R., Karčauskienè D., Katutis K. Sendžikienè E. 2013. The effect of meadow phytocenoses productivity and herbage quality on the energy value of biomass. Zemdirbvste-Agriculture. 100 (4): 349-354 http://dx.doi.org/10.13080/z-a.2013.100.044

Šarauskis E., Buragienė S., Masilionytė L., Romaneckas K., Avižienytė D., Saklauskas A. 2014. Energy balance, costs and $\mathrm{CO}_{2}$ analysis of tillage technologies in maize cultivation. Energy. 69: 227-235 http://dx.doi.org/10.1016/j.energy.2014.02.090

Tamulis T. 1986. Chemical composition and nutrition value of fodder. Vilnius, 278 p. (in Lithuanian)

The productivity of Lithuania's land. 2011 / compiled by Mažvila J. Lithuanian Research Centre for Agriculture and Forestry, 280 p. (in Lithuanian)

Tilvikienė V., Venclauskas K., Navickas K., Dabkevičius Z., Kadžiulienè Ž. 2012. The biomass production and biogas productivity of perennial grasses. Zemdirbyste-Agriculture, 99 (1): 17-22

Vaičiulytė R., Bakšienè E. 2011. Productivity of ecologic grassland phytocenosesin in simple Luvisols. Žemès ūkio mokslai, 18 (3): 100-108 (in Lithuanian)

Vaišvila Z., Arbačiauskas J. Mažvila J., Adomaitis T., Šumskis D. 2015. Changes in crop yields depending on the interaction of their nutrition elements. Innovative Soil Science and Plant Science Solutions: monograph, p. 236-243 (in Lithuanian)

Wang J. Y., Yan X. Y., Gong W. 2015. Effect of long-term fertilization on soil productivity on the North China Plain. Pedosphere. 25 (3): 450-458 http://dx.doi.org/10.1016/S1002-0160(15)30012-6

ISSN 1392-3196 / e-ISSN 2335-8947

Zemdirbyste-Agriculture, vol. 103, No. 2 (2016), p. 143-150

DOI 10.13080/z-a.2016.103.019

\title{
Energijos sukaupimas biomasėje taikant ịvairias žemėnaudas priesmėlio paprastajame išplautžemyje (Haplic Luvisol)
}

\author{
A. Kazlauskaitè-Jadzevičè, S. Marcinkonis, E. Bakšienè
}

Lietuvos agrarinių ir miškų mokslų centro Vokès filialas

\begin{abstract}
Santrauka
Straipsnyje ịvertinti ariamų žemių 21 metų laikotarpio renatūralizacijos procesų energijos sukaupimo biomasèje pokyčiai. Renatūralizacijos tyrimu aktualumas Pietryčių Lietuvoje yra nulemtas šios teritorijos dirvožemių dangos mažo našumo ir mažo energijos kiekio, gaunamo iš menkos agrarinės vertès dirvožemyje auginamų tradiciniu augalų. Tyrimo tikslas - ịvertinti ịvairius priesmèlio išplautžemio (Haplic Luvisol) renatūralizacijos būdus lyginant pušyne, dirvone ir kultūrinèje pievoje augintų augalų sukauptą bendrosios energijos kiekị su tradicinès žemdirbystès sistemos produktyvumu.

Ivairiose žemėnaudose sukauptas bendrosios energijos kiekis priklausè nuo augintu augalu ir ju auginimo trukmès. 1995-2015 m. laikotarpiu produktyvumo kitimo kryptis mažejančia linkme buvo: miško augalų (195 \%) $\rightarrow$ tręštos pievos $(162 \%) \rightarrow$ trešto sèjomainos lauko $(100 \%) \rightarrow$ netręštos pievos $(95 \%) \rightarrow$ netręšto sèjomainos lauko (61 $\%) \rightarrow$ dirvono $(50 \%$ ). Palyginus per visą tyrimo laikotarpị augintų augalu produktyvumą nustatyta, kad tręšimas mineralinėmis NPK trąšomis sejomainos lauko energinị produktyvumą esmingai padidino 1,63 karto. Pažymètina, kad kultūriniu žolynu produktyvumas nenaudojant mineraliniu trąšu prilygo treš̆to sèjomainos lauko produktyvumui, o patrę̌us NPK trąšomis ji viršijo net 67 \%. Tręšimas mineralinèmis NPK trąšomis kultūrinès pievos sukauptą bendrosios energijos kiekị esmingai padidino 1,71 karto. Dirvonuojančiuose laukuose energijos sukaupimas esmingai pakito. Nedirbamų priesmèlio dirvožemių natūraliai susiformavusi augalija yra neproduktyvi - joje sukaupiama dvigubai mažiau bendrosios energijos, palyginus su tręštu sejomainos lauku arba netrę̌sta kultūrine pieva.
\end{abstract}

Reikšminiai žodžiai: antžeminè biomasė, dirvonas, pieva, pušynas, sèjomainos laukas.

Please use the following format when citing the article:

A. Kazlauskaitè-Jadzevičè, S. Marcinkonis, E. Bakšienè. 2016. Energy value of biomass produced on various land uses in a sandy loam Haplic Luvisol. Zemdirbyste-Agriculture, 103 (2): 143-150 DOI 10.13080/z-a.2016.103.019 